\title{
Immunological function and antibacterial activity of two ferritin proteins from the freshwater pearl mussel Hyriopsis schlegelii
}

\author{
J.Q. Sheng ${ }^{1 *}$, Q.C. Shu ${ }^{1 *}$, J.W. Shi ${ }^{1}$, J.H. Wang ${ }^{1}$, K. Peng ${ }^{1}$, S. Yuan ${ }^{1}$ and \\ Y.J. Hong ${ }^{1,2}$ \\ ${ }^{1}$ Aquaculture Science Department, College of Life Sciences, \\ Nanchang University, Nanchang City, Jiangxi Province, China \\ ${ }^{2}$ Key Laboratory of Molecular Biology and Genetic Engineering of Jiangxi, \\ College of Life Sciences, Nanchang University, Nanchang City, \\ Jiangxi Province, China \\ *These authors contributed equally to this study. \\ Corresponding author: Y.J. Hong \\ E-mail: yijianghong@126.com
}

Genet. Mol. Res. 15 (3): gmr. 15038533

Received February 4, 2016

Accepted June 15, 2016

Published August 29, 2016

DOI http://dx.doi.org/10.4238/gmr.15038533

Copyright $\mathbb{C} 2016$ The Authors. This is an open-access article distributed under the terms of the Creative Commons Attribution ShareAlike (CC BY-SA) 4.0 License.

\begin{abstract}
Ferritin is a conserved iron-binding protein involved in host defense and cellular iron metabolism in most organisms. We investigated the expression profiles of two ferritin genes (designated HsFer-1 and HsFer-2) in the hemocytes, gonad, and hepatopancreas of Hyriopsis schlegelii, when challenged with bacteria and metal ions. HsFer gene transcription increased 1.8-7.7- and 1.9-6.1-fold in these tissues after stimulation with Staphylococcus aureus and Vibrio anguillarum, respectively. In addition, following exposure to $\mathrm{Fe}^{3+}$, expression of HsFer-1 and HsFer-2 was elevated by 1.5-6.1- and 3.610.1-fold, respectively. Levels of $\mathrm{HsFer-1}$ and -2 mRNA also increased
\end{abstract}


significantly after treatment with $\mathrm{Cu}^{2+}$ and $\mathrm{Pb}^{2+}$ at certain concentrations. Moreover, recombinant HsFer-1 and -2 were able to inhibit the growth of two strains of bacteria, and the former efficiently chelated $\mathrm{Fe}^{3+}$. From these results, we conclude that HsFer-1 and -2 may be involved in iron metabolism and immune defense by inhibiting the growth of bacteria.

Key words: Hyriopsis schlegelii; Ferritin; Immunological stress; Antibacterial activity; Chelate

\section{INTRODUCTION}

All eukaryotic ferritins are composed of 24 polypeptide chains that form a hollow spherical structure surrounding a cavity capable of storing up to $4500 \mathrm{Fe}^{3+}$ ions (Torti and Torti, 2002; Carrondo, 2003). Ferritin is composed of H- and L-subunits, the proportions of which vary in different tissues (Hasan et al., 2006). In invertebrates, these two subunits demonstrate different iron absorption and mineralization capacities (Harrison and Arosio, 1996). The H-subunit is composed of seven conserved residues conferring iron oxidase activity, and is able to rapidly convert $\mathrm{Fe}^{2+}$ to $\mathrm{Fe}^{3+}$. The L-subunit exhibits no iron oxidase activity, but its salt bridges stabilize its structure for iron nucleation and long-term storage (Santambrogio et al., 1992; Zhu et al., 2011). Some studies have reported the presence of an iron response element (IRE) in the ferritin 5'-untranslated region, which is considered the binding site for iron regulatory protein (IRP; Kato et al., 2001). $\mathrm{H}-$ and L-ferritins are both regulated highly efficiently according to iron concentration through the IRE-IRP system (Pantopoulos, 2004). The post-transcriptional regulation of ferritin has been extensively studied, and involves coordination of Iron Responsive Protein 1 and Iron Responsive Protein 2 and the Iron Regulatory Element (Hentze and Kühn, 1996).

Some reports have demonstrated that ferritin is involved in the immune response in many species, including Scophthalmus maximus (Zheng et al., 2010), Pseudosciaena crocea (Zhang et al., 2010), Patinopecten yessoensis (Zhang et al., 2013a), and Ruditapes philippinarum (Kim et al., 2012). Expression of genes encoding ferritins can be affected by high iron levels (Torti and Torti, 2002), oxidative stress (Tsuji, 2005), and heavy metal ions (Zhang et al., 2006). Furthermore, Wang et al. (2011) reported that recombinant CsFerM derived from Cynoglossus semilaevis completely inhibits the growth of six different bacterial fish pathogen species.

Since its introduction to China, Hyriopsis schlegelii has gradually become the principal species employed in the Chinese freshwater pearl industry because of its rapid growth and the good quality of its pearls. Our previous study has revealed that the two ferritin subunits of this species (HsFer-1 and HsFer-2) are of the H-type, and are involved in host immune defense (He et al., 2013). To obtain a better understanding of its function in immunity, we investigated ferritin mRNA levels after challenge with bacteria and heavy metal ions. In addition, bacteriostatic assays and tests of the iron-chelating activities of recombinant HsFer-1 (rHsFer-1) and HsFer-2 (rHsFer-2) were performed in this study.

\section{MATERIAL AND METHODS}

\section{Experimental animals and bacteria}

Healthy H. schlegelii averaging $131.0 \pm 10.2 \mathrm{~mm}$ in shell length (6-9 months old) were

Genetics and Molecular Research 15 (3): gmr.15038533 
collected from the Fuzhou Hongmen Reservoir Exploitation Corporation, Jiangxi Province, China, and acclimatized at $23^{\circ} \pm 2{ }^{\circ} \mathrm{C}$ in aerated fresh water for 3-5 days. The bacteria Vibrio anguillarum VIB1 (ATCC 43305) and Staphylococcus aureus (GIM1.221) were provided by the State Key Laboratory of Freshwater Ecology and Biotechnology, Institute of Hydrobiology, Chinese Academy of Sciences. All strains were cultured to mid-logarithmic phase in Lysogeny broth (LB) medium at $37^{\circ} \mathrm{C}$ and resuspended in phosphate-buffered saline (PBS).

\section{Challenge experiment}

Seventy mussels were randomly divided into challenge and control groups (35 individuals per group). For the former, $50 \mu \mathrm{L}$ live $V$. anguillarum or $S$. aureus was injected into the adductor muscle, and five mussels were randomly sampled $0,2,4,8,16,24$, and $48 \mathrm{~h}$ post-infection. Mussels in the control group were injected with $50 \mu \mathrm{L}$ PBS. For both groups, hemocytes, gonads, and hepatopancreas were collected for expression analysis. At each sampling point, equally sized tissue samples were taken from five mussels and ground into a powder in liquid nitrogen. All samples were homogenized in $1 \mathrm{~mL}$ Trizol reagent (Invitrogen, Carlsbad, CA, USA) and stored at $-80^{\circ} \mathrm{C}$ for subsequent procedures.

For the heavy metal challenge experiment, 140 mussels were used. These were randomly divided into four tanks (35 individuals per tank), and exposed to analytical-grade $\mathrm{Fe}^{3+}, \mathrm{Cu}^{2+}$, and $\mathrm{Pb}^{2+}$ at final concentrations of $4 \mathrm{~g} / \mathrm{L}, 15 \mathrm{mg} / \mathrm{L}$, and $12 \mathrm{mg} / \mathrm{L}$, respectively. The fourth tank served as a control group. The fresh water in each tank was changed every day. After $0,2,4,8,16,24$, and $48 \mathrm{~h}$, the hemocytes, gonad, and hepatopancreas of five mussels from each tank were collected for RNA extraction to analyze the temporal expression profile of HsFer-1 and HsFer-2. All collected samples were treated as above.

\section{RNA extraction and complementary DNA (cDNA) synthesis}

Total RNA extraction was accomplished using Trizol reagent following the manufacturer protocol. The purity and integrity of the extracted RNA was assessed with a microvolume spectrophotometer (NanoDrop 2000, Thermo Fisher Scientific, Waltham, MA, USA) and 1\% agarose gel electrophoresis, respectively. To eliminate genomic DNA contamination, RNA was treated with RQ1 RNase-free DNase (Promega, Madison, WI, USA) following the manufacturer protocol. DNase-treated RNA $(2 \mu \mathrm{L})$ from different tissues was used to synthesize cDNA utilizing Moloney murine leukemia virus reverse transcriptase (Promega), and the resulting cDNA samples were diluted 1:10 in nuclease-free water for use as a template.

\section{mRNA expression analysis by quantitative real-time polymerase chain reaction (qRT-PCR)}

HsFer-1 and HsFer-2 gene expression patterns in response to bacterial and metal ion $\left(\mathrm{Fe}^{3+}, \mathrm{Cu}^{2+}\right.$, and $\left.\mathrm{Pb}^{2+}\right)$ challenge were detected by qRT-PCR. The primers employed are listed in Table 1. Each reaction was prepared in a final volume of $20 \mu \mathrm{L}$, comprising $10 \mu \mathrm{L}$ SYBR Green PCR mix (Life Technologies, Carlsbad, CA, USA), $0.4 \mu \mathrm{L}$ each primer (10 nM), $8.4 \mu \mathrm{L}$ double-distilled $\mathrm{H}_{2} \mathrm{O}$, and $0.8 \mu \mathrm{L}$ cDNA template. The reaction conditions were as follows: an initial incubation at $94^{\circ} \mathrm{C}$ for $5 \mathrm{~min}$, then 40 cycles of $94^{\circ} \mathrm{C}$ for $30 \mathrm{~s}, 58^{\circ} \mathrm{C}$ for $30 \mathrm{~s}$, and $72^{\circ} \mathrm{C}$ for $30 \mathrm{~s}$. Each reaction was carried out in triplicate. Expression of $H s F e r$ genes was estimated 
using the $2^{-\Delta \Delta C t}$ method (Livak and Schmittgen, 2001). Statistical analysis was carried out with SPSS 19.0 software (IBM Corp., Armonk, NY, USA). Data (reported as means \pm standard deviations) were tested by one-way analysis of variance between the experimental and control groups. Statistical significance was determined with the Student $t$-test. In all cases, differences were considered significant at $\mathrm{P}<0.05$, and highly significant at $\mathrm{P}<0.01$.

Table 1. Primers used in the present study.
\begin{tabular}{l|l|l}
\hline Primer & Sequence $\left(5^{\prime}-3^{\prime}\right)$ & Sequence information \\
\hline P1 (forward) & CGGAATTCATGGCACAGACAAGACCAC & HsFer-1 ORF \\
\hline P2 (reverse) & CCCTCGAGAGTCCAATTTATTAGGGCTG & \\
\hline P3 (forward) & CGGGATCCATGGCACAGACAAGACCACGTC & HsFer-2 ORF \\
\hline P4 (reverse) & CCCTCGAGAAGCATTTTGAGCAAGATTC & \\
\hline P5 (forward) & CACTGGGCTGGATGCAATGGAAG & HsFer-1 qRT-PCR \\
\hline P6 (reverse) & CCAAGTCCAGGTCCAACACGCT & HsFer-2 qRT-PCR \\
\hline P7 (forward) & AGCCGGTATCAACAAGCAAATC & \\
\hline P8 (reverse) & ATGCTCTCTCTCCTCCTCAG & $\beta$-Actin qRT-PCR \\
\hline P9 (forward) & AAGGTTACGCCCTTCCTCAT & \\
\hline P10 (reverse) & GCCATTTCCTGCTCAAAGTC \\
\hline ORF $=$ open reading frame, qRT-PCR = quantitative real-time polymerase chain reaction.
\end{tabular}

\section{Iron-chelating activity assay}

The iron-chelating activity of purified rHsFer-1 was determined based on the method of Boyer and McCleary (1987; Decker and Welch, 1990). Briefly, rHsFer-1 was dissolved in water to a concentration of $60 \mu \mathrm{g} / \mathrm{mL}$. A total of $20 \mu \mathrm{L} 2.5 \mathrm{mM} \mathrm{FeCl}_{3}$ was combined with 100 $\mu \mathrm{L}$ rHsFer-1 (treatment group) or $100 \mu \mathrm{L}$ elution buffer (control group). Then, elute buffer was added up to $1 \mathrm{~mL}$ to samples from both groups. The mixtures were subsequently shaken at room temperature for $60 \mathrm{~min}$. To convert $\mathrm{Fe}^{3+}$ to $\mathrm{Fe}^{2+}, 40 \mu \mathrm{L} \mathrm{1 \%} \mathrm{L-ascorbic} \mathrm{acid} \mathrm{was} \mathrm{mixed}$ with the samples by shaking for $20 \mathrm{~min}$, and $40 \mu \mathrm{L} 5 \mathrm{mM}$ ferrozine was subsequently added (Sangon, Shanghai, China). After incubation for $10 \mathrm{~min}$ at room temperature, the optical density (OD) of each sample at $562 \mathrm{~nm}$ was detected with a spectrophotometer. Measurements were repeated three times to obtain the average absorbance value used to calculate the ironchelating activity of rHsFer-1. This was estimated according to the following formula: [C - (C$\mathrm{S})] / \mathrm{C} \times 100 \%$, where $\mathrm{C}$ and $\mathrm{S}$ represent the absorbance values of the control and treatment samples, respectively.

\section{Bacteriostatic activity analysis}

Recombinant proteins were purified as described in a previous publication (He et al., 2013). The bacteriostatic activity of $\mathrm{rHsFer}-1$ and $\mathrm{rHsFer}-2$ was evaluated using a bacterial growth inhibition assay based on a slightly modified procedure (Zheng et al., 2010). First, $V$. anguillarum and $S$. aureus were grown to mid-logarithmic phase in LB medium at $37^{\circ} \mathrm{C}$. Then, these bacterial solutions were diluted 1:50 or 1:100 and cultured until their OD at 600 $\mathrm{nm}\left(\mathrm{OD}_{600}\right)$ was approximately 0.4 . Two aliquots of bacterial suspension were treated with rHsFer-1 or rHsFer-2, at final concentrations of 40 and $80 \mu \mathrm{g} / \mathrm{mL}$. A further aliquot was mixed with an equivalent volume of PBS as the control group. All samples were cultured by shaking $(220 \mathrm{rpm})$ at $37^{\circ} \mathrm{C}$. We assessed the bacterial growth with detecting the turbidimetric method by measuring the $\mathrm{OD}_{600}$ at 2 -h intervals over $10 \mathrm{~h}$ with a visible-light spectrophotometer. Every measurement was taken three times for each assay. 


\section{RESULTS}

\section{HsFer-1 and HsFer-2 gene expression in response to bacterial infection}

To assess the expression of HsFer-1 and HsFer-2 in response to bacterial challenge, healthy $H$. schlegelii were exposed separately to $V$. anguillarum and S. aureus. Hepatopancreases, gonads, and hemocytes were then collected to analyze levels of ferritin mRNA by qRT-PCR at various intervals $(0,2,4,8,16,24$, and $48 \mathrm{~h}$ post-challenge). Expression levels are reported as fold-changes compared to that of the control group.

As shown in Figure 1A, the relative expression of HsFer-1 mRNA in hemocytes slowly increased to 1.79 -fold $(\mathrm{P}>0.05)$ by $24 \mathrm{~h}$ after exposure to $S$. aureus, whereas its lowest level of 0.53 -fold $(\mathrm{P}<0.05)$ was observed after $48 \mathrm{~h}$. The presence of HsFer-1 transcripts in these cells decreased and increased at each interval after challenge with $V$. anguillarum, the highest expression $(2.30$-fold; $\mathrm{P}<0.05)$ being measured after $48 \mathrm{~h}$ (Figure 1B). HsFer-2 mRNA levels in hemocytes appeared to be up-regulated to two time points after exposure to $S$. aureus, firstly at $4 \mathrm{~h}(1.80$-fold; $\mathrm{P}<0.05)$, then at $24 \mathrm{~h}(1.71$-fold; $\mathrm{P}<0.05$; Figure $1 \mathrm{C})$. Following challenge with $V$. anguillarum, hemocyte expression of $H_{s} F e r-2$ increased gradually from $0-4 \mathrm{~h}$, peaking at 4.32 -fold $(\mathrm{P}<0.01)$, then decreasing to a low of 0.58 -fold $(\mathrm{P}<0.05)$ at $8 \mathrm{~h}$. The initial level was subsequently maintained from $16-48 \mathrm{~h}$ (Figure 1D).

In gonad tissue, after treatment with $S$. aureus or $V$. anguillarum, $H_{s} F e r-1$ expression was the highest after $8 \mathrm{~h}$, reaching values of 7.69- $(\mathrm{P}<0.01)$ and 4.43 -fold $(\mathrm{P}<0.01)$, respectively (Figures 1A and 1B). HsFer-2 levels in this tissue peaked to 2.25 -fold $(\mathrm{P}<0.01)$ at $24 \mathrm{~h}$ following injection of $S$. aureus. In response to $V$. anguillarum, HsFer-2 expression increased and decreased at intervals from 2 to $16 \mathrm{~h}$, with a peak value at $8 \mathrm{~h}$ of 4.76 -fold $(\mathrm{P}<$ 0.01 ; Figures $1 \mathrm{C}$ and 1D).

In the hepatopancreas, $H_{s} F e r-1$ mRNA levels increased gradually from $0-4 \mathrm{~h}$ after exposure to $S$. aureus, eventually reaching 2.83 -fold $(\mathrm{P}<0.05)$. Then, expression decreased to its lowest level $(0.38$-fold $)$ at $8 \mathrm{~h}(\mathrm{P}<0.05)$, before rising to a second high point of 2.16 -fold $(\mathrm{P}<0.05)$ at $24 \mathrm{~h}$ (Figure 1A). However, as Figure 1B shows, transcription appeared to be repeatedly up- and down-regulated from 0 to $48 \mathrm{~h}$ following $V$. anguillarum challenge, peaking at $16 \mathrm{~h}(6.05$-fold; $\mathrm{P}<0.01$; Figure 1B). Expression of HsFer-2 in the hepatopancreas after treatment with $S$. aureus displayed changes similar to those observed in relation to HsFer-1 following $V$. anguillarum challenge. The highest value of 2.33 -fold $(\mathrm{P}<0.01)$ was recorded at $24 \mathrm{~h}$ (Figure 1C). As a result of exposure to $\mathrm{V}$. anguillarum, HsFer-2 levels peaked twice, at 2.86 -fold $(\mathrm{P}<0.05)$ after $2 \mathrm{~h}$, and 1.90 -fold $(\mathrm{P}<0.05)$ after $48 \mathrm{~h}$ (Figure 1D).

\section{Temporal expression of $\mathrm{HsFer-1}$ and $\mathrm{HsFer}-2$ in response to iron ion exposure}

To examine whether HsFer-1 and HsFer-2 mRNA transcription is modulated by $\mathrm{Fe}^{3+}$, the expression of these genes was investigated in the hemocytes, gonad, and hepatopancreas (Figure 2). In hemocytes, transcription of $H s F e r-1$ was lowest $(0.18$-fold; $\mathrm{P}<0.01)$ at $4 \mathrm{~h}$, and a peak of 1.53-fold $(\mathrm{P}<0.05)$ was measured at $24 \mathrm{~h}$ (Figure 2A). Meanwhile, HsFer-2 mRNA levels increased to the highest $(3.59$-fold; $\mathrm{P}<0.05)$ after $2 \mathrm{~h}$ and were the lowest $(0.57$-fold $)$ at $24 \mathrm{~h}$ (Figure 2B). HsFer-1 expression reached a high of 6.14-fold $(\mathrm{P}<0.01)$ in gonad tissue after $2 \mathrm{~h}$, then decreased rapidly to its original level (Figure 2A). The lowest level of HsFer-2 transcription ( 0.76 -fold; $\mathrm{P}>0.05)$ in this tissue was observed at $4 \mathrm{~h}$, and the highest (4.29-fold;

Genetics and Molecular Research 15 (3): gmr.15038533 
$\mathrm{P}<0.01)$ at $8 \mathrm{~h}$ (Figure 2B). Expression in the hepatopancreas of HsFer-1 increased slowly, to finally peak at $24 \mathrm{~h}(2.74$-fold; $\mathrm{P}<0.05$; Figure $2 \mathrm{~A})$. That of $H_{s} F e r-2$ was strikingly elevated in this tissue, with two high points of 8.57- $(\mathrm{P}<0.01)$ and 10.10 -fold $(\mathrm{P}<0.01)$ at 2 and $24 \mathrm{~h}$, respectively (Figure 2B).
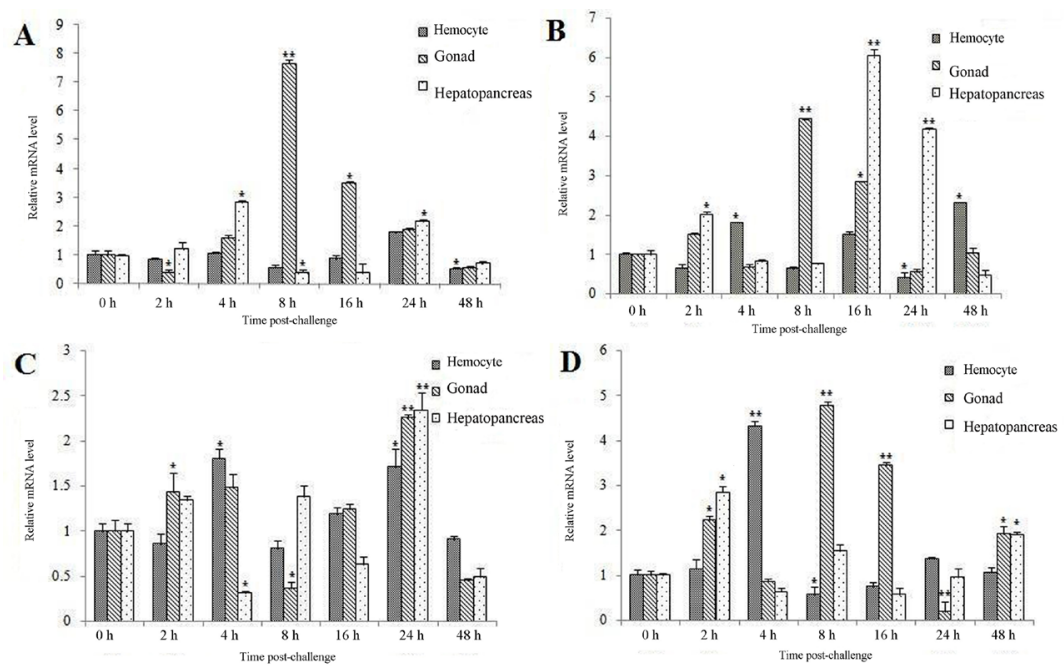

Figure 1. Expression levels of HsFer-1 (A and B) and HsFer-2 (C and $\mathbf{D})$ were measured by quantitative realtime polymerase chain reaction in the hemocytes, gonad, and hepatopancreas of Hyriopsis schlegelii challenged by Vibrio anguillarum (B and $\mathbf{D}$ ) and Staphylococcus aureus (A and $\mathbf{C}$ ). Bars and error bars represent means \pm standard deviations $(\mathrm{N}=3)$. Significant differences between challenge and control groups are indicated with asterisks $(* \mathrm{P}<0.05, * * \mathrm{P}<0.01)$.
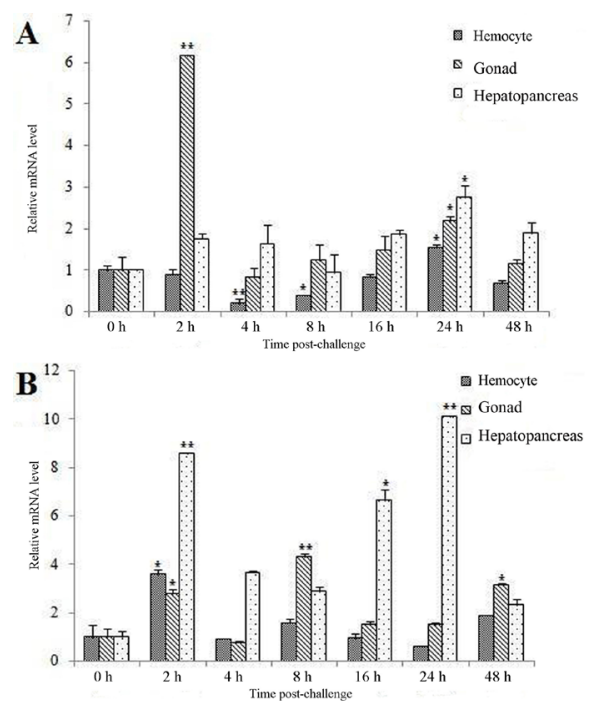

Figure 2. Expression levels of HsFer-1 (A) and HsFer-2 (B) were measured by quantitative real-time polymerase chain reaction in the hemocytes, gonad, and hepatopancreas $0,2,4,8,16,24$, and $48 \mathrm{~h}$ after $\mathrm{FeCl}_{3} \cdot 6 \mathrm{H}_{2} \mathrm{O}$ exposure. Bars and error bars represent means \pm standard deviations $(\mathrm{N}=3)$. Significant differences between challenge and control groups are indicated with asterisks $(* \mathrm{P}<0.05, * * \mathrm{P}<0.01)$.

Genetics and Molecular Research 15 (3): gmr.15038533 


\section{Temporal expression of $\mathrm{HsFer}-1$ and $\mathrm{HsFer}-2$ after heavy metal challenge}

qRT-PCR was performed to test $H_{s F e r-1}$ and $H s F e r-2$ expression in the hemocytes, gonad, and hepatopancreas after $\mathrm{Cu}^{2+}$ and $\mathrm{Pb}^{2+}$ challenge. As depicted in Figures $3 \mathrm{~A}$ and 3B, following treatment with $\mathrm{Cu}^{2+}$, levels of both $\mathrm{HsFer}_{s}-1$ and $\mathrm{HsFer}_{s} 2$ distinctly increased in hemocytes, reaching the maximum values of 9.37 -fold $(\mathrm{P}<0.01)$ after $4 \mathrm{~h}$ and 3.65 -fold ( $\mathrm{P}$ $<0.05$ ) after $2 \mathrm{~h}$, respectively. However, expression of these genes was unchanged in the hepatopancreas, remaining at baseline levels (Figures 3A and 3B). In the gonad, HsFer-1 levels were up-regulated to a high of 9.61-fold at $16 \mathrm{~h}(\mathrm{P}<0.01$; Figure $3 \mathrm{~A})$, before being down-regulated from 16 to $48 \mathrm{~h}$. HsFer-2 expression reached a peak value of 12.64-fold at 8 $\mathrm{h}(\mathrm{P}<0.01$; Figure 3B).

Levels of HsFer-1 mRNA did not increase and HsFer-2 mRNA only increased at 48 $\mathrm{h}$ in hemocytes after challenge with $\mathrm{Pb}^{2+}$ (Figures 3C and 3D), whereas in the gonad, peak increases of 4.14- $(\mathrm{P}<0.01)$ and 4.02-fold $(\mathrm{P}<0.01)$, respectively, were measured at $2 \mathrm{~h}$. In the hepatopancreas, expression of $\mathrm{HsFer}_{\mathrm{S}} \mathrm{l}$ and $\mathrm{HsFer}_{\mathrm{S}} 2$ remained essentially constant from $0-16 \mathrm{~h}$, and reached a maximum of 1.76- $(\mathrm{P}<0.05)$ and 2.61 -fold $(\mathrm{P}<0.05)$, respectively, after $48 \mathrm{~h}$.
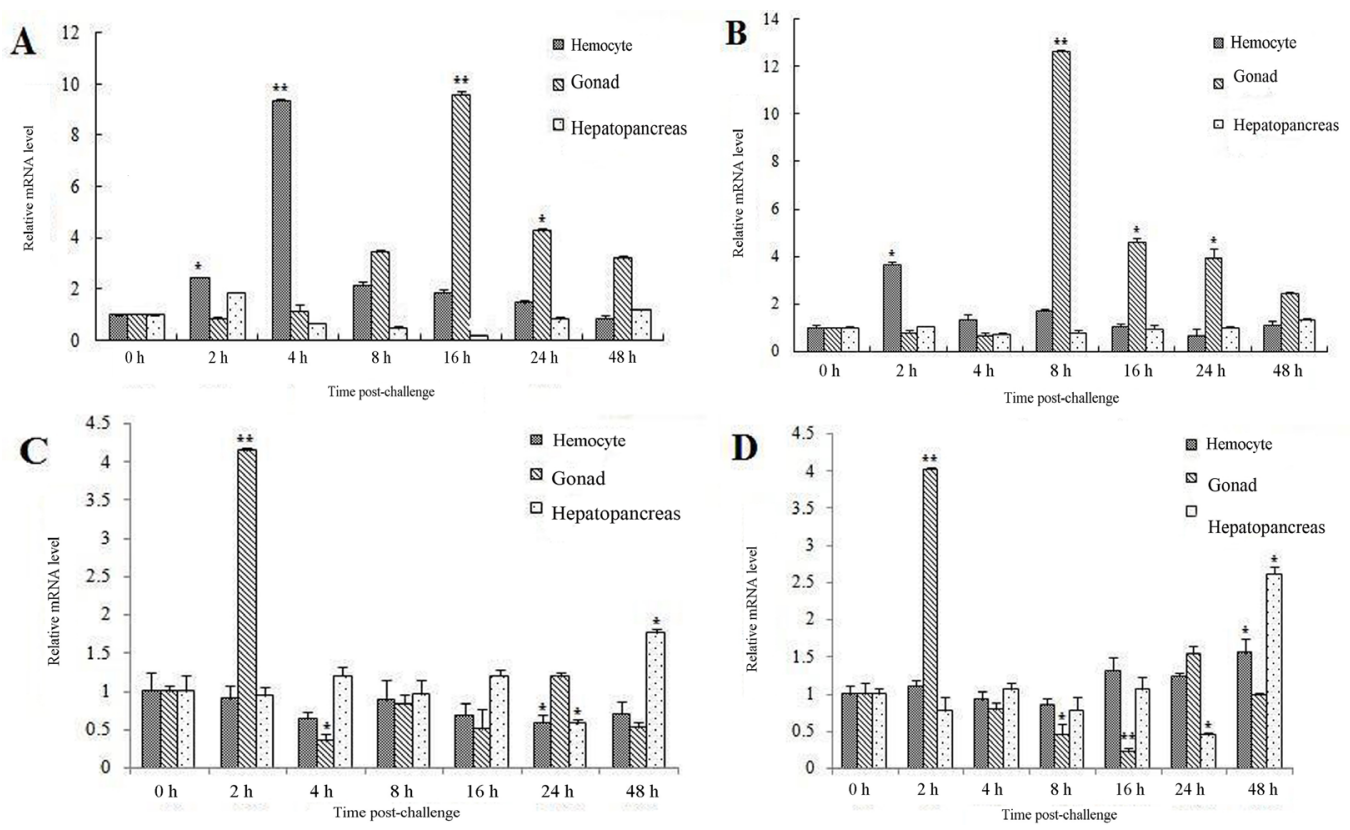

Figure 3. Time course of HsFer-1 (A and C) and HsFer-2 (B and D) mRNA expression measured by quantitative real-time polymerase chain reaction in the hemocytes, gonad, and hepatopancreas of Hyriopsis schlegelii after $\mathrm{Cu}^{2+}(\mathbf{A}$ and $\mathbf{B})$ and $\mathrm{Pb}^{2+}(\mathbf{C}$ and $\mathbf{D})$ exposure. Bars and error bars represent means \pm standard deviations $(\mathrm{N}=3)$. Significant differences between challenge and control groups are indicated with asterisks $\left(* \mathrm{P}<0.05,{ }^{*} \mathrm{P}<0.01\right)$.

\section{Analysis of rHsFer-1 $\mathrm{Fe}^{3+}$ chelation}

In order to investigate whether rHsFer-1 possesses the fundamental property of ferritin, an iron-chelating assay for ferroxidase activity was performed using the $\mathrm{Fe}^{2+}$-specific 
reagent ferrozine. The solution containing ferritin exhibited an absorbance value at $562 \mathrm{~nm}$ of 0.109 , while for the control solution, this value was 0.277 . At a concentration of $6 \mu \mathrm{g} / \mathrm{mL}$, the $\mathrm{Fe}^{3+}$-chelating activity of rHsFer-1 was calculated to be $39.35 \%$.

\section{Bacteriostatic effect of rHsFer-1 and rHsFer-2}

To investigate the antibacterial efficacy of purified rHsFer-1 and rHsFer-2, the growth of $V$. anguillarum and $S$. aureus was measured in the absence and presence of these proteins at different concentrations. Clear antibacterial activity was observed by detecting light absorbance at $600 \mathrm{~nm}$, revealing that $\mathrm{rHsFer}-1$ and $\mathrm{rHsFer}-2$ inhibited the growth of both bacterial strains. Figures $4 \mathrm{~A}$ and $4 \mathrm{~B}$ demonstrate that $\mathrm{rHsFer}-1$ exerted the strongest inhibitory effect against $S$. aureus and $V$. anguillarum at 2 and $6 \mathrm{~h}$, respectively. Extremely significant inhibition of $S$. aureus growth was apparent at $10 \mathrm{~h}$ after addition of rHsFer-2 (Figure 4C), the antibacterial activity of which was not as strong in liquid medium containing V. anguillarum (Figure 4D). In addition, the inhibitory effect of the two recombinant proteins was dose-dependent. When the concentrations of rHsFer-1 and rHsFer-2 were raised from 40 to $80 \mu \mathrm{g} / \mathrm{mL}$, their antibacterial potency increased significantly.
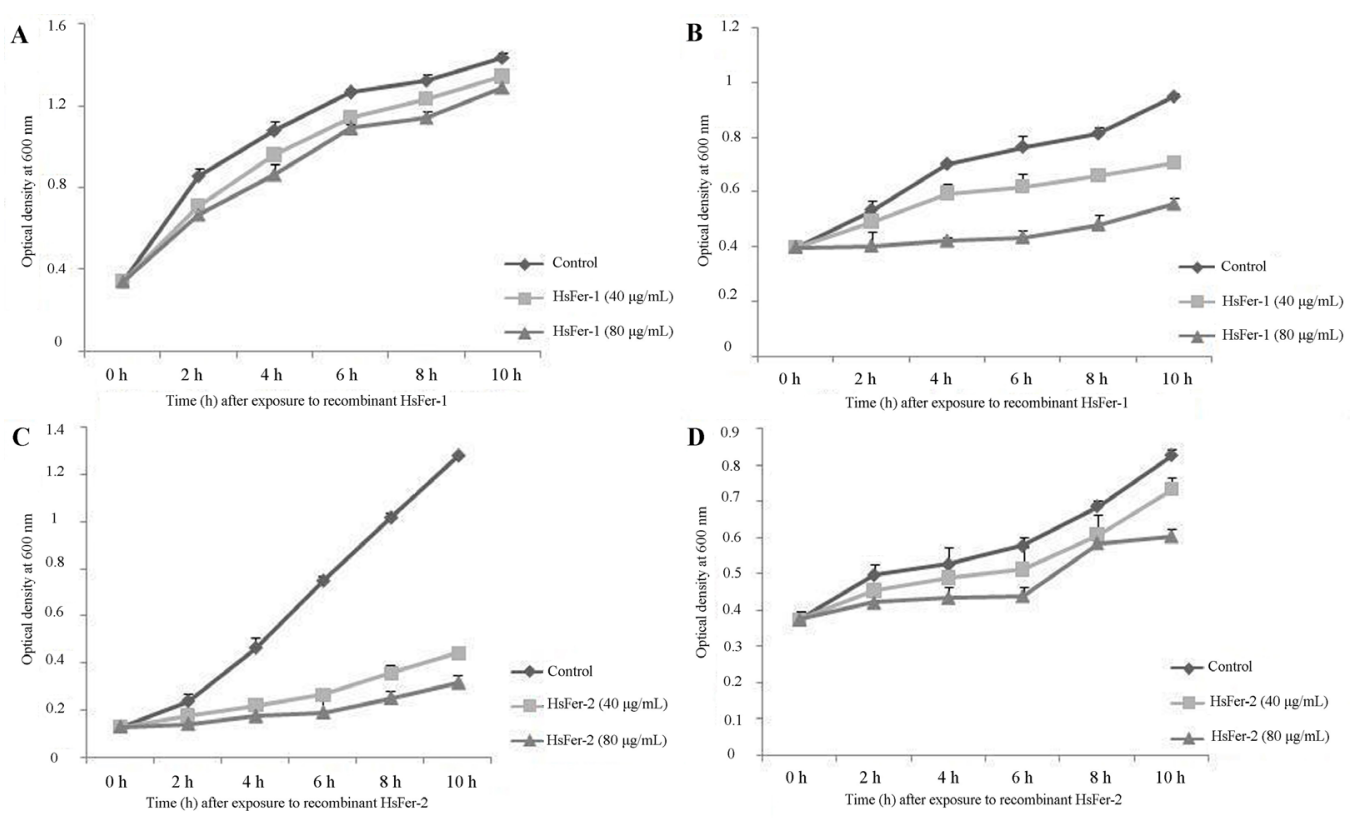

Figure 4. Bacteriostatic activity of recombinant HsFer-1 (rHsFer-1; $\mathbf{A}$ and $\mathbf{B})$ and $\mathrm{rHsFer-2}$ (C and D) against Vibrio anguillarum (B and $\mathbf{D}$ ) and Staphylococcus aureus (A and $\mathbf{C})$. Cell densities were determined by measuring light absorbance at $600 \mathrm{~nm}$ at various time points. Values derive from at least three assays and are reported as means \pm standard deviations $(\mathrm{N}=3)$.

\section{DISCUSSION}

Ferritins are regarded as acute-phase proteins that respond to stress and inflammation. In lower vertebrates such as fish, ferritin synthesis is modulated by microbial infections. For 
instance, expression levels of ferritin in Atlantic cod and red drum are elevated by exposure to the bacterial pathogens Aeromonas salmonicida and Edwardsiella tarda (Feng et al., 2009; $\mathrm{Hu}$ et al., 2010). Compared to vertebrate ferritins, less attention has been paid to invertebrate forms, and only Beck et al. (2002) have reported that echinoderm ferritins are involved in innate immunity. In addition, heightened expression has been observed in Saccostrea cucullata and Argopecten irradians following challenge with the pathogens Vibrio harveyi and Listonella anguillarum (Zhu et al., 2011; Li et al., 2012).

Expression levels of HsFer-1 and HsFer-2 have been shown to be up-regulated in the hepatopancreas, gonad, and hemocytes after exposure to Aeromonas hydrophila; thus, ferritin is thought to be involved in host immune defense (He et al., 2013). It is interesting to consider whether Gram-positive and -negative bacteria bring about different levels of ferritin expression in $H$. schlegelii. $\mathrm{H}$ and $\mathrm{M}$ ferritins are up-regulated in the liver, spleen, and kidney of $P$. crocea in response to an attenuated live strain of the Gram-negative bacterium V. anguillarum (Zhang et al., 2010). Certain researchers have also speculated that Gram-negative bacteria more potently induce S. maximus Fer-1 than Gram-positive strains (Zheng et al., 2010). In our study, levels of HsFer-1 and HsFer-2 mRNA increased in the gonad and hepatopancreas during challenge with $S$. aureus and $V$. anguillarum. This result is similar to those obtained with $P$. yessoensis (Zhang et al., 2013a), Pinctada martensii (Wang et al., 2012), Mya arenaria (Araya et al., 2010), Venerupis philippinarum (Zhang et al., 2013b), and Saccostrea glomerata (Taylor et al., 2013). As an acute-phase protein, ferritin can be up-regulated as a result of infection, especially during those involving bacteria (Feng et al., 2009; Hu et al., 2010). One hypothesis posits that ferritins protect against microbial infection by depriving pathogenic organisms of nutrients in an ironwithholding strategy (Raetz and Whitfield, 2002). Here, the two ferritin subunits seemed to respond differently to $S$. aureus and $V$. anguillarum. For instance, although $H_{s} F e r-2$ expression was dramatically elevated in reaction to both bacteria in the hepatopancreas and gonad, it was more sensitive to $V$. anguillarum challenge. That is, the maximum level of $H s F e r-2$ transcription in these two tissues occurred 2 and $8 \mathrm{~h}$ after $V$. anguillarum infection, respectively, but peaked at $24 \mathrm{~h}$ following $S$. aureus challenge. This is consistent with ferritin expression in the Yesso scallop (P. yessoensis; Zhang et al., 2013a). In contrast, the highest HsFer-1 mRNA levels were recorded at $16 \mathrm{~h}$ following initial exposure to $V$. anguillarum, but after only $4 \mathrm{~h}$ of $S$. aureusinduced stress. These results suggest that each subunit might serve a different purpose in the innate immunity of $H$. schlegelii against diverse challenges.

From another perspective, we found that $\mathrm{HsFer}_{\mathrm{s}}$ expression levels varied greatly in the same tissues after stimulation by the same bacteria, implying that different ferritin subtypes may play divergent roles. In the present study, ferritin expression tended to peak before returning to its baseline value. In addition, previous data have established that ferritin synthesis is affected by inflammatory processes, including reactions to bacterial injection. Together, these findings indicate that ferritin is an immune-enhancing protein, the production of which increases in response to particular stimuli. Given these results, we can conclude that the elevation of ferritin expression may be a protective mechanism to alleviate pressure.

Few reports concerning the effect of ferritin on bacterial growth have been published. Ferritin from $R$. philippinarum has been shown to demonstrate noticeable anti-bacterial activity in its suppression of Vibrio tapetis growth (Kim et al., 2012). It has also been reported that four purified recombinant ferritins from $P$. yessoensis are able to inhibit proliferation of the scallop pathogen $V$. anguillarum (Zhang et al., 2013b). In this study, the inhibitory effect of rHsFer-1 on $V$. anguillarum was appreciably stronger than that against $S$. aureus. The cell

Genetics and Molecular Research 15 (3): gmr.15038533 
walls of Gram-positive bacteria are known to comprise a three-dimensional structure composed of teichoic acid and a large amount of peptidoglycan. By contrast, those of Gram-negative bacteria consist of a two-dimensional planar formation containing less peptidoglycan. As is well known, lipopolysaccharide (LPS) is a key component of the outer membranes of Gram-negative bacteria, but is not present in those of Gram-positive species. As an endotoxin, LPS can induce a series of immune responses by promoting the secretion of pro-inflammatory cytokines (Zheng et al., 2010). In this context, our results suggest that LPS may elevate ferritin expression, which inhibits bacterial growth. However, although ferritin exhibits clear bacteriostatic effects, the mechanism by which rHsFer-1 and rHsFer-2 bring about such inhibition requires further study.

Ferritin plays important roles in the metabolism of iron, including the regulation of its concentration and its detoxification (Zhang et al., 2013b). As demonstrated in disk abalone (De Zoysa and Lee, 2007), turbot (Zheng et al., 2010), and red drum (Hu et al., 2010), purified recombinant ferritin is able to bind iron. This attribute explains ferritin's efficacy, via the ironwithholding strategy, as part of the host innate immune response against microbial infections (Bradford, 1976). These observations prompted us to perform an in vitro bacteriostatic test of the two $H$. schlegelii ferritins. The results were similar to those obtained with turbot, revealing that recombinant ferritin inhibits the growth of pathogens (Zheng et al., 2010). Variations in the intensity of inhibition may be due to the different bacterial strains used in each protocol. In our iron challenge experiment, expression of the two $\mathrm{HsFer}_{\mathrm{s}}$ genes significantly increased. As expected, this demonstrates that the corresponding proteins could be involved in iron regulation, as with ferritins in abalone (Wu et al., 2010) and clams (Jin et al., 2011; Li et al., 2011). Our study revealed HsFer-1 and HsFer-2 transcription to be regulated by iron concentration. Therefore, in addition to their storage and detoxification functions, ferritins act against microbial infection by sequestering host iron. Besides the effect of iron, we investigated the induction of ferritin expression by other heavy metal ions by challenging $H$. schlegelii with $\mathrm{Cu}^{2+}$ and $\mathrm{Pb}^{2+}$. We found that both of these metals could cause up-regulation of HsFer genes, in a similar manner to that in Chinese shrimp (Fenneropenaeus chinensis; Zhang et al., 2006).

To date, there have been few reports regarding the chelation of $\mathrm{Fe}^{3+}$ by ferritin in H. schlegelii. The present study revealed that this protein can successfully generate chelate complexes with $\mathrm{Fe}^{3+}$ ions.

\section{Conflicts of interest}

The authors declare no conflict of interest.

\section{ACKNOWLEDGMENTS}

Research supported by the National Natural Science Foundation of China (\#31160534), the Scientific and Technological Program of Jiangxi Province, China (\#KJLD 12001 and \#2009BNA07400), and the Natural Science Foundation of Jiangxi Province (\#20122BAB204016).

\section{REFERENCES}

Araya MT, Markham F, Mateo DR, McKenna P, et al. (2010). Identification and expression of immune-related genes in hemocytes of soft-shell clams, Mya arenaria, challenged with Vibrio splendidus. Fish Shellfish Immunol. 29: 557564. http://dx.doi.org/10.1016/j.fsi.2010.05.017

Genetics and Molecular Research 15 (3): gmr.15038533 
Beck G, Ellis TW, Habicht GS, Schluter SF, et al. (2002). Evolution of the acute phase response: iron release by echinoderm (Asterias forbesi) coelomocytes, and cloning of an echinoderm ferritin molecule. Dev. Comp. Immunol. 26: 11-26. http://dx.doi.org/10.1016/S0145-305X(01)00051-9

Boyer RF and McCleary CJ (1987). Superoxide ion as a primary reductant in ascorbate-mediated ferritin iron release. Free Radic. Biol. Med. 3: 389-395. http://dx.doi.org/10.1016/0891-5849(87)90017-7

Bradford MM (1976). A rapid and sensitive method for the quantitation of microgram quantities of protein utilizing the principle of protein-dye binding. Anal. Biochem. 72: 248-254. http://dx.doi.org/10.1016/0003-2697(76)90527-3

Carrondo MA (2003). Ferritins, iron uptake and storage from the bacterioferritin viewpoint. EMBO J. 22: 1959-1968. http://dx.doi.org/10.1093/emboj/cdg215

De Zoysa M and Lee J (2007). Two ferritin subunits from disk abalone (Haliotis discus discus): cloning, characterization and expression analysis. Fish Shellfish Immunol. 23: 624-635. http://dx.doi.org/10.1016/j.fsi.2007.01.013

Decker EA and Welch B (1990). Role of ferritin as a lipid oxidation catalyst in muscle food. J. Agric. Food Chem. 38: 674-677. http://dx.doi.org/10.1021/jf00093a019

Feng CY, Johnson SC, Hori TS, Rise M, et al. (2009). Identification and analysis of differentially expressed genes in immune tissues of Atlantic cod stimulated with formalin-killed, atypical Aeromonas salmonicida. Physiol. Genomics 37: 149-163. http://dx.doi.org/10.1152/physiolgenomics.90373.2008

Harrison PM and Arosio P (1996). The ferritins: molecular properties, iron storage function and cellular regulation. Biochim. Biophys. Acta 1275: 161-203. http://dx.doi.org/10.1016/0005-2728(96)00022-9

Hasan MR, Koikawa S, Kotani S, Miyamoto S, et al. (2006). Ferritin forms dynamic oligomers to associate with microtubules in vivo: implication for the role of microtubules in iron metabolism. Exp. Cell Res. 312: 1950-1960. http://dx.doi.org/10.1016/j.yexcr.2006.02.023

He S, Peng K, Hong Y, Wang J, et al. (2013). Molecular properties and immune defense of two ferritin subunits from freshwater pearl mussel, Hyriopsis schlegelii. Fish Shellfish Immunol. 34: 865-874. http://dx.doi.org/10.1016/j. fsi.2012.12.021

Hentze MW and Kühn LC (1996). Molecular control of vertebrate iron metabolism: mRNA-based regulatory circuits operated by iron, nitric oxide, and oxidative stress. Proc. Natl. Acad. Sci. USA 93: 8175-8182. http://dx.doi. org/10.1073/pnas.93.16.8175

$\mathrm{Hu}$ YH, Zheng WJ and Sun L (2010). Identification and molecular analysis of a ferritin subunit from red drum (Sciaenops ocellatus). Fish Shellfish Immunol. 28: 678-686. http://dx.doi.org/10.1016/j.fsi.2010.01.001

Jin C, Li C, Su X and Li T (2011). Identification and characterization of a Tegillarca granosa ferritin regulated by iron ion exposure and thermal stress. Dev. Comp. Immunol. 35: 745-751. http://dx.doi.org/10.1016/j.dci.2011.02.006

Kato J, Fujikawa K, Kanda M, Fukuda N, et al. (2001). A mutation, in the iron-responsive element of H ferritin mRNA, causing autosomal dominant iron overload. Am. J. Hum. Genet. 69: 191-197. http://dx.doi.org/10.1086/321261

Kim H, Sandaruwan Elvitigala DA, Lee Y, Lee S, et al. (2012). Ferritin H-like subunit from Manila clam (Ruditapes philippinarum): molecular insights as a potent player in host antibacterial defense. Fish Shellfish Immunol. 33: 926936. http://dx.doi.org/10.1016/j.fsi.2012.08.007

Li C, Li H, Su X and Li T (2011). Identification and characterization of a clam ferritin from Sinonovacula constricta. Fish Shellfish Immunol. 30: 1147-1151. http://dx.doi.org/10.1016/j.fsi.2011.02.017

Li J, Li L, Zhang S, Li J, et al. (2012). Three ferritin subunits involved in immune defense from bay scallop Argopecten irradians. Fish Shellfish Immunol. 32: 368-372. http://dx.doi.org/10.1016/j.fsi.2011.10.030

Livak KJ and Schmittgen TD (2001). Analysis of relative gene expression data using real-time quantitative PCR and the $2^{(-\mathrm{D} \mathrm{DC}(\mathrm{T}))}$ Method. Methods 25: 402-408. http://dx.doi.org/10.1006/meth.2001.1262

Pantopoulos K (2004). Iron metabolism and the IRE/IRP regulatory system: an update. Ann. N. Y. Acad. Sci. 1012: 1-13. http://dx.doi.org/10.1196/annals.1306.001

Raetz CR and Whitfield C (2002). Lipopolysaccharide endotoxins. Annu. Rev. Biochem. 71: 635-700. http://dx.doi. org/10.1146/annurev.biochem.71.110601.135414

Santambrogio P, Levi S, Arosio P, Palagi L, et al. (1992). Evidence that a salt bridge in the light chain contributes to the physical stability difference between heavy and light human ferritins. J. Biol. Chem. 267: 14077-14083.

Taylor DA, Thompson EL, Nair SV and Raftos DA (2013). Differential effects of metal contamination on the transcript expression of immune- and stress-response genes in the Sydney Rock oyster, Saccostrea glomerata. Environ. Pollut. 178: 65-71. http://dx.doi.org/10.1016/j.envpol.2013.02.027

Torti FM and Torti SV (2002). Regulation of ferritin genes and protein. Blood 99: 3505-3516. http://dx.doi.org/10.1182/ blood.V99.10.3505

Tsuji Y (2005). JunD activates transcription of the human ferritin $\mathrm{H}$ gene through an antioxidant response element during oxidative stress. Oncogene 24: 7567-7578. http://dx.doi.org/10.1038/sj.onc.1208901

Genetics and Molecular Research 15 (3): gmr.15038533 
Wang W, Zhang M and Sun L (2011). Ferritin M of Cynoglossus semilaevis: an iron-binding protein and a broad-spectrum antimicrobial that depends on the integrity of the ferroxidase center and nucleation center for biological activity. Fish Shellfish Immunol. 31: 269-274. http://dx.doi.org/10.1016/j.fsi.2011.05.012

Wang Y, Fu D, Luo P and He X (2012). Identification of the immune expressed sequence tags of pearl oyster (Pinctada martensii, Dunker 1850) responding to Vibrio alginolyticus challenge by suppression subtractive hybridization. Comp. Biochem. Physiol. Part D Genomics Proteomics 7: 243-247. http://dx.doi.org/10.1016/j.cbd.2012.03.004

Wu C, Zhang W, Mai K, Xu W, et al. (2010). Transcriptional up-regulation of a novel ferritin homolog in abalone Haliotis discus hannai Ino by dietary iron. Comp. Biochem. Physiol. C Toxicol. Pharmacol. 152: 424-432. http://dx.doi. org/10.1016/j.cbpc.2010.07.002

Zhang J, Li F, Wang Z, Zhang X, et al. (2006). Cloning, expression and identification of ferritin from Chinese shrimp, Fenneropenaeus chinensis. J. Biotechnol. 125: 173-184. http://dx.doi.org/10.1016/j.jbiotec.2006.03.010

Zhang L, Sun W, Cai W, Zhang Z, et al. (2013b). Differential response of two ferritin subunit genes (VpFer1 and VpFer2) from Venerupis philippinarum following pathogen and heavy metals challenge. Fish Shellfish Immunol. 35: 16581662. http://dx.doi.org/10.1016/j.fsi.2013.07.030

Zhang X, Wei W, Wu H, Xu H, et al. (2010). Gene cloning and characterization of ferritin $\mathrm{H}$ and $\mathrm{M}$ subunits from large yellow croaker (Pseudosciaena crocea). Fish Shellfish Immunol. 28: 735-742. http://dx.doi.org/10.1016/j. fsi.2009.11.027

Zhang Y, Zhang R, Zou J, Hu X, et al. (2013a). Identification and characterization of four ferritin subunits involved in immune defense of the Yesso scallop (Patinopecten yessoensis). Fish Shellfish Immunol. 34: 1178-1187. http:// dx.doi.org/10.1016/j.fsi.2013.01.023

Zheng WJ, Hu YH, Xiao ZZ and Sun L (2010). Cloning and analysis of a ferritin subunit from turbot (Scophthalmus maximus). Fish Shellfish Immunol. 28: 829-836. http://dx.doi.org/10.1016/j.fsi.2010.01.013

Zhu B, Lin Q, Ke CH and Huang HQ (2011). Single subunit type of ferritin from visceral mass of Saccostrea cucullata: cloning, expression and cisplatin-subunit analysis. Fish Shellfish Immunol. 31: 453-461. http://dx.doi.org/10.1016/j. $\underline{\text { fsi.2011.06.020 }}$

Genetics and Molecular Research 15 (3): gmr.15038533 